by the National Academy of Sciences and the National Research Council, respectively. At the same time, the following officers were re-elected: President, Dr. Harlow Shapley, director of Harvard College Observatory; Vice-President and Chairman of the Executive Committee, Dr. Alexander Wetmore, secretary of the Smithsonian Institution ; Treasurer, O. W. Riegel, director of Lee School of Journalism, Washington and Lee University; Secretary, Watson Davis, director of Science Service. Additional members elected to the Executive Committee were Frank R. Ford, editor, Evansville Press, Evansville, Ind., and Dr. Karl Lark-Horovitz, Purdue University. Science Service is an endowed, non-profit-making institution for the popularization of science. The board of trustees consists of three representatives each from the American Association for the Advancement of Science, the National Academy of Sciences, the National Research Council, the journalistic profession, and the Scripps Estate. The address of Science Service is 1719 N St., N.W., Washington 6, D.C.

\section{An Unusual Solar Halo}

Mr. J. E. Bowman, Armament Research Establishment, Foft Halstead, Kent, writes : "On Niay 10 at Shoebur ness I observed a solar halo of an unusual size. Fof about the last hour before sunset a welldefined parhelion of the $22^{\circ}$ halo was visible to the north of the sun; but there was no trace of the $22^{\circ}$ halo itself. Just after the sun had set, however, the upper part of the $22^{\circ}$ halo appeared, accompanied by a much smaller halo, the radius of which I estimated to be about $8-9^{\circ}$, and a sun pillar extending to some $15^{\circ}$ above the sun. A patch of relatively greater brightness appeared where the sun pillar intersected the $8^{\circ}$ halo. The whole spectacle, which lasted until a quarter of an hour after sunset, was extremely faint and could be distinguished only with difficulty. The display of halo phenomena continued after dark, for at 10 p.m. the moon was accompanied by the two paraselenæ of the $22^{\circ}$ halo. Again, however, there was no trace of the $22^{\circ}$ halo itself.'

\section{Co-operation between Universities and Technical Colleges}

Is his address to a recent meeting of the Yorkshire Council for Furthenducation, Sir Ronald Weeks, chairman of the National Advisory Council for Education frifustry and Commerce, discussed the need formich closer co-operation between universities and technical colleges (Tech. J., 41, No. 4; Ap 1 1949). Considering the place of the graduate in industry, Sir Ronald said that more attention should be given to the possibility of strengthening the science graduate on the technological side, and the Higher National Certificate student on the science side. Arrangements should also be made whereby graduate students could attend special courses of technology at the technical college either by block release or part-time study. Sir Ronald Weeks suggested certain principles for the provision of arrangements of this kind which must be observed. Among these are the following: both universities and technical colleges must be considered available for meeting the needs, having regard to their present facilities or possible future facilities; the convenience and needs of the students must come first, particularly in the case of part-time students ; technical colleges must not be regarded as the poor relations of the universities, as this is fatal to co-operation and good understanding; there must be an easy means of transfer of students from universities to technical colleges, and vice versa.

\section{Earthquakes during March}

At least elevennotong earthquakes occurred in the world during Nirch. The greatest, and also the deepesty hasened on March 4 from a focus having an spictntre near lat. $36 \cdot 5^{\circ} \mathrm{N}$., long. $70 \cdot 5^{\circ} \mathrm{E}$., in the H rdu Kush, Afghanistan. The depth of focus was probably rather greater than $200 \mathrm{~km}$. and the strength $7 \frac{1}{2}$ on the instrumental scale. Owing to its strength and depth, the shock was felt over a wide area in Afghanistan and the North-West Frontier Province, Pakistan, and although the full extent of the damage is not yet assessed, the earthquake is known to have damaged the Roman Catholic cathedral in Lahore. The next most intense (scale $c$. 7) was probably that occurring on March 27 from a focus having an epicentre in the Celebes Sea off the southern coast of Cape Mindanoa. Strong shocks on March 16 and 17 had their epicentres in the region of the Bismarck Archipelago. On March 9 an earthquake with strength $5 \frac{1}{2}$ and epicentre near lat. $37 \cdot 1^{\circ} \mathrm{S}$., long. $121 \cdot 3^{\circ} \mathrm{W}$., in central California set off burglar alarms and rolled. stones off Telegraph Hill, San Francisco, but did no serious damage. At Hollister some windows and plaster were cracked, and small objects were shaken off shelves. Of the small shocks during the month, three may be mentioned. On March 7 an earthquake was felt with strength 3-4 on the Modified Miercalli scale in the south-west Alps near Messtetten. It had a depth of focus, according to Dr. W. Hiller, of Stuttgart, of less than $5 \mathrm{~km}$. On March 11 a strong tremor shook the area around Dalton, New South Wales, Australia, and cracked buildings there, causing damage estimated at $£ 2,000$. The shock was felt in Sydney and Canberra. On March 22 an earthquake was felt in the Département des Basses-Alpes, France, doing some damage at Lauzet. Instrumental readings for the month have been received from the central stations of the United States Coast and Geodetic Survey in co-operation with Science Service and the Jesuit Seismological Association; the Central Seismological Bureau at Strasbourg; and individual observatories at De Bilt (Netherlands), Durham, Stuttgart and Toledo.

\section{Tellus : A New Journal of Geophysics}

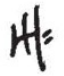

THE Second World War has brought losses and also gains in the ppiracal literature of geophysics. Among the gails Tellus, a quarterly journal of geophysics ifsued by the Swedish Geophysical Society. CVol. 1, No. 1, February 1949, consists of 64 pages, and is obtainable from the Department of Mefperplogy, University of Stockholm, price 2 U.S. doNars. The Society was founded in 1920 to promote research and international collaboration in geophysies; but the institution of a regular journal is a new departure made possible by a Government grant and by the co-operation of the Lithographic Institution of the General Staff. Contributions, to be printed in English, French or German, are invited on all branches of geophysics, from all countries. The first issue, however, is practically an all-Swedish one, the authors concerned being Pettersson, Rydbeck and Stranz, Palmén, Bergeron, Nyberg, Rossby, Ahlmann, and Ångström. Five of the contributions are meteorological; one is ionospheric, being on the 
effects of solar flares; and two relate to marine expeditions, one prospective and the other that of the Albatross, to obtain sediment cores to study the geochronology of the deep ocean bed.

\section{Institution of Mining and Metallurgy}

The second Sir Julius Wernher Memorial Lecture of the Institution of Mining and Metallurgy will be given by Dr. C. H. Desch, who will speak on "The Effect of Impurities on the Properties of Metals". The Lecture will be delivered at the Royal Institution, 21 Albemarle Street, London, W.1, on July 6, at 5 p.m., and admission is free and without ticket.

The Institution will be holding a symposium on "The Refining of Non-Ferrous Mietals" during July $7-8$ at the Royal Institution of Chartered Surveyors, 14 Great George Street, Westminster, London, S.W.1. Tickets of admission (which are free) and further information may be obtained from the Secretary, Institution of Mining and Metallurgy, Salisbury House, Finsbury Circus, London, E.C.2.

\section{Canadian Scholarship Awards}

SCHOLARSHAs have been granted by the National Research gouncil of Canada to 165 graduates to enable them to pursue postgraduate studies during the academic year 1949-50. There are nineteen fell wships at 900 dollars, sixty-four studentships at 700 dollars and seventy-eight bursaries at 450 dollars tenable at Canadian universities, and four special scholarships at 750 dollars awarded for study outside Canada. The nominal value of all scholarships for the year is 103,200 dollars as compared with the total for last year of 148 scholarships worth 97,050 dollars. Physics is represented by 65 , and chemistry, in its several branches, by 59. The remainder are distributed in the other sciences as follows: bac. teriology, 1 ; biology, 4; communications engineering, 1; cytogenetics, 1; electrical engineering, 2 ; geology, 3 ; histology, 2 ; mathematics, 3 ; medical research, 2; microwave studies, 1; metallurgy, 2; mineralogy, 2 ; nutrition, 1 ; physical metallurgy, 2 ; physiology, 1; radiation studies, 2 ; spectroscopy, 3 ; zoology, 8.

\section{Colonial Service: Recent Appointments}

THE following appointments in the Colonial Service have been announced: G. Swaine, entomologist, Tanganyika; R. L. Woolridge, veterinary officer, Kenya E. Pawson, agricultural chemist, Northern BXodesia; K. L. Richards, livestock officer, Africultural Department, Cyprus; A. J. Whitakch, electrical engineer, Nigeria ; J. L. King (depyly electrical engineer-in-chief, Nigeria), electrigal engineer-in-chief, Nigeria; J. M. Stock (senior electrical engineer, Nigeria), deputy electrical engineer-in-chief, Nigeria; J. R. Lockie (conservator of forests, Nigeria), assistant chief conservator of forests, Nigeria; R. Smeathers (assistant conservator of forests, Trinidad), deputy conservator of forests, Trinidad; J. H. Bowen (senior inspector of plants and produce, Gold Coast), chief inspector of plants and produce, Gold Coast; A. H. Fetherstonhaugh (control officer, Game Department, Federation of Mialaya), chief game warden, Federation of Mialaya; T. P. Lecky (agricultural officer, grade 2, Jamaica), senior livestock officer, Jamaica; W. G. Stuart (agricultural officer, grade 2, Jamaica), agricultural officer, grade 1, Jamaica; C. Teesdale (entomological field officer, Kenya), entomologist, Kenya.

\section{Telecommunications at the Imperial College}

Standard Telephones and Cables, Ltd., have endowed a readership, to be known as the Henry Mark Pease readership in telecommunications, in the City and Guilds College of the Imperial College of Science and Technology, London. Henry Mark Pease, one of the pioneers of the telephone industry in Britain, who died in March 1947, was managing director of Standard Telephones and Cables, Ltd., until 1928; he took an active part in forming the British Broadcasting Company, of which he was one of the original directors. Mr. E. C. Cherry has been appointed to the new readership. Mr. Cherry was attached to the Telecommunication Research Establishment of the Miinistry of Aircraft Production during the war period and is known particularly for his contributions to the subject of electric circuit analysis.

\section{The British Society for International Under- standing}

Sir Arthur Hall has been elected chairman of the British Sbciety for International Understanding in succession to Mr. G. M. Young, the historian and literary critic, who has retired after holding the chairmanship since the Society's incorporation ten years agf. Sir Arthur Hall is director of studies at the Royal Naval College, Greenwich, and is also chairman of the English Association. Mr. Young remains chairman of the Editorial Committee of the Society's publication, The British Survey. Mr. Oliver Bell has been succeeded as vice-chairman of the Society by Colonel John Grace, of British Columbia, formerly director of education of the Canadian Army in Britain during the War.

\section{Linnean Society of London: Officers for 1949}

THE following have been elected officers of the Linneap Society of London for the session 1949-50: Presjent, Prof. F. E. Fritsch; Treasurer, Colonel F. C. Stern; Secretaries, Dr. B. Barnes (botany) and Dr. A. Tindell Hopwood (zoology); New Members of Council, Prof. A. J. E. Cave, Dr. E. B. Ford, C. C. Hentschel and Dr. C. F. A. Pantin.

\section{Announcements}

Mir. Gaoffrey Munday, of the South-West Essex Techpreal College, who has been carrying out research on the temperature variation of the optical properties of gold, has been appointed a research-associate at the Massachusetts Institute of Technology.

A Summer School IN X-Ray Analysis, somewhat simila to those held in Manchester and Cambridge in previous years, is to be held in Leeds during the period August 29-September 10. Further information can be obtained from Prof. E. G. Cox, Department of Inorganic and Physical Chemistry, University, Leeds 2.

THE French Association for the Advancement of Sciences will hold its sixty-eighth annual congress a Clermont-Ferrand, during July 15-21.

Erratum. In a footnote to the communication entitled "Inelastic Scattering of Protons by Mag. nosium and Aluminium" in Nature of May 28, p. 848 , the present address of the author, E. H. Rhoderick, is wrongly stated; it should be Department of Natural Philosophy, University of Glasgow. 